\title{
Metastatic Renal Cell Carcinoma
}

National Cancer Institute

\section{Source}

National Cancer Institute. Metastatic Renal Cell Carcinoma. NCI Thesaurus. Code C150595.

Renal cell carcinoma which has spread from the kidney to other anatomic sites. 